NEW LITERARIA-

An International Journal of Interdisciplinary Studies in Humanities

Volume 1, No. 2, November-December, 2020, PP 137-145

ISSN: 2582-7375

DOI: https://dx.doi.org/10.48189/nl.2020.v01i2.006

www.newliteraria.com

\title{
Languages of Resistance: Women in the Print and Oral Cultures of Colonial Punjab
}

\author{
Arti Minocha
}

\begin{abstract}
Print Culture Studies as a new field of enquiry has facilitated the reassessment of the 'postcolonial' by taking into account power relationships between 'publics' and the colonial state through the use of print technology. Scholars have expressed the need for revisionary histories of South Asian print cultures from postcolonial perspectives that move beyond tropes of violence and victimhood to 'agency' of the colonial subject. To answer the question, "Can the subaltern speak through print", this essay looks at women in print and oral cultures of late- $19^{\text {th }}$ and early-20th century Punjab, especially through the question of language politics. The reform organisations in Punjab advocated the one-language, one-community formula, especially in so far as prescribed languages for women were concerned. Despite the tight surveillance over the print sphere by the colonial authorities and the reform organisations, it was inhabited and constituted by women in a variety of ways that defied this control. The essay locates women's agency and resistance of the postcolonial subject through their choice of languages and genres of expression. Official publication records of translation activity and multilingual publishing are used to trace inter-textuality between languages and scripts that contradict the linkage of language with religion and script and that had much to do with women's reading, writing, and oral practices. Women reading and speaking in languages not prescribed by the reform movements and accessing literature and genres proscribed for them, indicate that the subaltern did speak.
\end{abstract}

Keywords: Print Cultures; Punjab Print; Print Cultures; Language Policy.

\section{Introduction}

One of the ways in which the 'postcolonial' can be rethought, is to take into account power relationships between the 'publics' and the colonial state, exercised through the use of print technology, surveillance mechanisms, and language policies, and the modes through which print cultures became the locus of 'agency' of the colonial subjects. The perspectives and methodologies of "Print Culture Studies" offer new ways of assessing the impact of print cultures, which were a crucial part of modernity, on colonial societies. Scholars have expressed the need for revisionary histories of South Asian print cultures "viewed through critical, postcolonial eyes" (Fraser, 2008, p.14), that contest narratives of unilinear flow of European modernity to the colonies, and disruptions in oral and scriptural traditions and vernacular languages, said to have been caused by colonial interventions. This essay is an attempt to ask the question that has been posed by print culture scholars - if the subaltern can speak through print (Dharwadker, 1997). If print cultures and their surveillance were used by the colonial state for 'moral' and religious instruction to ensure compliance of the native subjects, how could the 'subaltern' speak, indeed? 
The main tropes that print histories have used to trace the impact of print technology on colonial societies have largely been social reform and the development of nationalist consciousness. This essay, however, attempts to look at women in public and print spheres of late- $19^{\text {th }}$ and early- $20^{\text {th }}$ century Punjab, especially through the question of language politics. The question of languages in postcolonial theory has been posed in terms of 'colonial' language versus the vernaculars. I argue that the binary of anti-colonial nationalism in the vernacular languages in opposition to colonial language, English in the case of India, is an understanding that needs re-assessment.

Punjab presents a unique case in which the language designated by the colonial state as the vernacular (Urdu) was not the language spoken and as widely understood as Punjabi. While Urdu was the state-designated official vernacular language, Punjabi, Hindi, and Urdu were identified as languages of Sikhs, Hindus, and Muslims by reform organisations and the colonial state. ${ }^{1}$ In Punjab, gender and religious identities were mediated through the use of languages, which were used to demarcate communities from each other. The reform organisations advocated the one-language, one-community formula, especially in so far as prescribed languages for women were concerned. Despite the tight surveillance over the print sphere by the colonial authorities and the reform organisations, it was inhabited and constituted by women in a variety of ways that defied this control. Rather than examining the language question through the trope of 'violence', I wish to look at the idea of 'resistance' of the colonial subject. My essay addresses this question of women's agency and resistance of the postcolonial subject through their choice of languages and genres of expression. I use official publication records of translation activity and multilingual publishing to suggest an inter-textuality that contradicts the linkage of language with religion and script and that had much to do with women's reading, writing, and oral practices.

\section{Language Practices and the Print Sphere in Punjab}

Readership patterns and vernacular publishing in Punjab were complicated by the competitive politics between languages and the designation of Urdu as the official vernacular and the identification of Punjabi, Hindi, and Urdu as languages of Sikhs, Hindus, and Muslims respectively by reform organisations. After the designation of Urdu as the vernacular in 1854, it received state patronage through translation bureaus, education departments, missionary and government presses, and became the dominant language of publication. In contrast, as Mir notes, Punjabi print did not get any state patronage and was market-reliant (2010, p. 14). The flourishing of Punjabi print despite lack of state patronage is an evidence of its popular, market demand. Writing about Punjabi publishing, Mohan Singh says,

Our villager has a medium through which at any time to vent his or her comments on current affairs in the shape of a folksong and get it printed and sold through hired musical reciters in the streets of Lahore and Amritsar. And these little poems sell, even amongst the educated classes. (n.d., p. 95)

Farina Mir provides evidence from the poetry of the Sufi saint Sheikh Farid, janam-sakhi literature (biographies of Guru Nanak), seventeenth century poets such as Sultan Bahu and Damodar, and histories of Punjab to conclude that Punjabi was the spoken language whereas

\footnotetext{
${ }^{1}$ The Arya Samaj, founded by Dayanand Saraswati in 1875, the Ahmaddiya movement founded in 1889 and the Singh Sabha founded in 1873 were socio-religious reform movements of the Hindus, Muslims and Sikhs respectively. These movements had many followers and are important to understand the social landscape of nineteenth century Punjab. Apart from their concerns with reforms in religion and women's education, they also led to the hardening of religious identities.
} 
Persian was the language of administration and literary production (pp. 35-36). In addition, she cites Administration Reports of 1873-4, Census of 1881, and George Grierson's Linguistic Survey of India to prove that Punjabi was the spoken language in the Punjab region (pp. 47-49). Sivaramakrishnan indicates that in Punjab, "print-based popular deployment was not always an accurate indicator of the ideological commitment and support that existed for the vernacular in question" (Sivaramakrishnan, 2006, p. 61). In other words, while Urdu was the officially designated vernacular for Punjab and dominated the print sphere, it was not spoken and understood widely.

Interestingly, the earliest Reports on Publications, published by the colonial government in Punjab from 1867, used genre rather than languages as a mode of classification of the material published. As the Reports begin to use language as a classificatory mode, the 'confusion' between languages and scripts becomes imminent. When we still use terms such as the 'Punjabi print sphere', for example, to refer to a language, we assume a stable, isolated entity of Punjabi language, which is far from truth. Such classifications are not imminent, and elide over the cultural processes that produced such distinctions in the first place. The instability of the language-script association is evident in the Report of 1882 as it struggles to list the various characters employed for vernacular languages $^{2}-$ Urdu in Gurmukhi, Persian, Nagri and Roman character, Punjabi in Gurmukhi, Persian or Arabic, and Nagari character and Hindi in Gurmukhi, Persian and Nagari characters.

As languages got identified with communities, one also finds attempts by the Education Department officials to classify books through the language-religion-script continuum: "But the so-called Punjabi books written by Muhammadan authors in the Persian character and containing a large percentage of Persian and Arabic words, with only a sprinkling of Punjabi, are more Urdu than Punjabi, and they form about 25 percent of publications classed as Punjabi." 3

Mohan Singh, in his history of Punjabi literature, written in the 1930s, says that strands in the "web of Panjabi literature" can be fathomed by employing Punjabi as a generic term that includes Lahndi, Central Panjabi or Sikkhi, Sahaskriti or Old Hindwi, Bhakha or Hindwi, Braji, Lahori, Awadhi and Jatki" (pp. 5-7). Commenting on its twentieth century usage and politicisation, he says that Punjabi is so "free" that it accommodates various inflections, moods, stanzaic arrangements so that there is nothing sacrosanct about it and that it "is altogether innocent of the various literary creeds of regionalism or communalism or 'capitalism", the last term being used for the "phonetics and usages of the pure-blooded aristocracy resident in the 'civil lines' of a Capital city" (p. 9). Further, he says,

On the general basic relation between Panjabi and Urdu or Hindi, the average uneducated Panjabi reveals a very illuminating psychology. In conversation with a person from the United Provinces, the Panjabi citizen only replaces $d a$ of his present tense and his preposition by $t a$ and $k a$ respectively and feels that he is now speaking Urdu and Hindi and is on a level with the other party in the matter of language, mutually intelligible. And he is right. For, phonetic peculiarities apart, the difference between Low Panjabi and Low Urdu for ordinary purposes, do not go much farther than implied in the above popular conception. (Singh, n.d., p. 9)

\footnotetext{
2 "Catalogue of Books Registered in the Punjab During the Quarter ending 30 $0^{\text {th }}$ September 1873" in Home Public (B), No. 252-55, December 1874.

${ }^{3}$ A report compiled by Khalifa Imad-ud-Din, Reporter on books in the Education Department, Punjab, in Report on Publications Issued and Registered in Several Provinces of British India during the Year 1912.
} 
For the same reason, compiling an "Index of Titles in Oriental Languages" presented itself as a problem at the India Office Library in London, where Punjabi, written in "two different Oriental scripts are concurrently used for the same language. ${ }^{4}$ On the one hand, then, the classification of print languages in records sought to create definitive linguistic understandings and associations of languages with religion and script, on the other hand, the translation activity and bilingual, trilingual, and polyglot publishing registered in these records suggests an inter-textuality that contradicts the linkage of language with religion and script.

\section{Languages and Women}

Periodicals published for women in the late-19th and early-20 $0^{\text {th }}$ century such as Panchal Pandita, Bharat Bhagini, and Jyoti in Hindi and Punjabi Bhain, Istri Samachar, Istri Sudhar Patra, Bhujangan Patra, etc. in Punjabi attempted to create communities of women homogenised through language and religion and therefore, seemed to corroborate with the one language-one community formula. This commitment to language was reaffirmed in many periodicals by women as well, as they were encouraged to produce literary work in the language of the community, thus contributing to the solidification of the language and the “quam” (Punjabi Bhain August 1910).

Panchal Pandita, a monthly for women exhorted them to speak and write in Hindi, the rashtrabhasha that had originated from Sanskrit but in Punjab had been 'defiled' by mixing with Urdu, Lahnda, and Gurmukhi. Yet, these deliberate attempts were undermined by the multiplicity of languages and registers, especially among women. For instance, Rameshwari Nehru, editor of women's periodical Stri Darpan (1909-28, Allahabad), encouraged Hindu women from Punjab to read her Hindi periodical because they lacked their own language. She welcomed women from Punjab to write in Hindi though their language use was 'compromised' and even announced publication of a series of poems in Punjabi to encourage the readership of her periodical in Punjab (Nijhawan, 2012, p. 222). This clearly indicates that despite institutional efforts, Hindi did not find much readership amongst women in Punjab even till the late 1920s.

Publications needed to cater to multiple audiences with different linguistic competencies - the older generation of munshis and elite grounded in Persian, people educated through Urdu in the newly-instituted vernacular education system, women more conversant with Punjabi, and the Hindi audience created due to the efforts of the Nagari Pracharini Sabha. According to Mohan Singh (a writer mentioned before), the demand for Punjabi publications and translations came from "Sikhs of all classes, from Hindu women and from low-educated Muslims of the rural areas on the one side and on the other from school boys and girls and from a very small minority of collegians" (Singh, n.d., p.79).

The need for intertextuality between languages comes through various other publications as one gleans through Reports on Publications and "Catalogues of Books Registered" - Urdu Zuban ki Pehli Kitab Gurmukhi Harfon Mein (a primer for Urdu in Gurmukhi), a Punjabi-Urdu reader, Gurmukhi vich Urdu di Pahli Kitab, (Balmukand Press, Lahore, 1910), Bhai Hardit Singh's, Bahar-i-Punjab (Wazir-i-Hind Press, 1910) that contained songs from various theatres in Gurmukhi, and Bhai Jodh Singh's, Vyakhyan Sikh Dharam Par (Bombay Press, Lahore) in Hindi in Persian character (as mentioned in

\footnotetext{
${ }^{4}$ Education Books (A), No. 1-5, January 1919.
} 
"Catalogue of Books"). ${ }^{5}$ These catalogues abound in exchange between languages and scripts, providing a rich array of combinations - Sindhi in Gurmukhi and Persian script, Punjabi in Arabic character, Urdu in Gurmukhi and Hindi character and Hindi in Gurmukhi character. Strishiksha, a reader for women and girls, lithographed and published in Lahore in 1876 teaches the alphabet in Hindi through the Gurmukhi script, indicating the mode through which Hindi could be taught to women. Books for women that taught the Hindi alphabet and letter writing in Hindi did so through Punjabi.

In his story of Bhagyavati, Pandit Shradda Ram Phillouri is concerned about the language which can be accessible to women so that they could be benefitted from the story. He says in the introduction that the book has been written in easy Hindi so that it is close to the speech of men and women who speak Poorvi Punjabi (Phillouri, 1887, p. 3). In his book Punjabi Geet (1927, Hindi Press, Lahore) on women's songs sung on different occasions, Sant Ram chooses the Devanagari script but says that sanskritised Hindi will not be accessible to most women since they were not literate. So, the songs in Punjabi are printed in Devanagari, with Hindi equivalence of Punjabi words given to familiarise women with Hindi. The picture on the title page of the book showing an Arya Samaj havan with women reading appropriate songs from books tells us how women's songs and languages were sanitised. The advertisement for Mohan Singh Vaid's, Tibb Akbari in Punjabi reassures the readers that someone who is barely literate can understand the book easily since it is in the spoken idiom of Punjabi. The use of language and script from these sources then does give us a fair idea about the gendered audiences that these books were intended to reach, and points to the resistance offered to colonial policy and reform prescriptions by the linguistic practices of women.

\section{Reading and Resistance: The Genres that Women were Reading}

The resistance to prescriptions and surveillance of the colonial state and reform organisations can also be located in the genres that women were reading. Commercial literature in the vernacular and very often, literature published by reform organisations attempted to sanitise women's behavioural practices in private and public spaces as well as the genres which they read. ${ }^{6}$ Yet, they did so through language and imagery that itself was voyeuristic and prurient, thus undercutting the notions of morality that they sought to convey. In the Report on Publications 1888, Lala Ram Kishan, officiating Registrar writes, "It is painful to observe in some few instances, the immoral and indecent language used in the uncouth literature of some of the so called religious and social reformers."

Numerous publications of romances, songs, qissas, prurient books thinly veiled as sex

\footnotetext{
5"Catalogue of Books Registered in the Punjabduring the Quarter ending 31 December 1910", IOR, SV 412/44.

${ }^{6}$ An example of a popular qissa that condemned the worshipping of saints is Sultan Poara (1896) by Bhai Ditt Singh Gyani that continued to be published well into the first decade of the twentieth century. Published in Punjabi, in the Gurmukhi script, it is a dialogue between a Sikh and a Hindu who worships the saint Sakhi Sarwar. Some more examples are Bhai Ditt Singh's Gugga Gapaura (1902) that describes the wiles of Gugga pir, Qissa Sultan Siyapa, The Curse of Sultanism, against Sakhi Sarwar's creed, by Pandit Gokal Chand (1902), Bhai Waryam Singh's, Gahi Shah Pir (1911), narrating the bad effects of attending fairs, Bhai Sadhu Singh's, Manmatian Nun Chaper (1912), against worshipping idols and snakes, Istri Dharm Simriti Sar (1912) by Bhai Mohan Singh Vaid, expounding select verses from the Shastras on the chastity of women and the custom of fasting and other superstitions observed by Hindu women, Sithniyan (1912) by Bhai Suraj Singh, a book of 'respectable'marriage songs for Sikh women, Istriyon ka Pahrawa (1901, Hindi in Gurmukhi character) by Lala Dev Raj on respectable dressing for women, Ih tan Garki Ai, Arthat Bhaire Pehreve de Augan (1901), evils of wearing indecent dresses by Khalsa Tract Society.
} 
manuals that are documented in the Reports on Publications reveal a reading culture beyond the literary tastes prescribed by the reform organisations. The Report 1898 indicates that two or three publications seemed to be so immodest that the matter had to be referred to the police authorities for necessary action. The writer comments on the abundance of "love verses, street ballads written for the masses, and as long as the taste of the masses does not improve, it is impossible to expect any change for the better in the character of such compositions. They are crude insipid things and remain the same from year to year."

There are several evidences that women were active consumers of such 'bazaar literature'. A tract published by the Khalsa Tract Society, Hir Ware Shah de Phal ("The Consequences of Reading Waris Shah's Hir", 1898), warns women that they should give up reading of love tales like Hir and devote their leisure to the study of religious books, in the process acknowledging that women's reading subverted reform prescriptions. The Report 1898 which mentions this book also expresses the fear that coarse, crude vernacular poetry is making its way into homes and to women readership.

Qissas describing illicit love, sexual experiences of women and homosexual love continued to be published in several reprints year after year with huge sales. For example, Bhai Gurdit Singh's Jhagra Nuh Sauhra (1917), a tale of illicit love between a father-in-law and daughter-in-law, sold 3000 copies just in one quarter, inspiring him to write titles such as Nawan Qissa Budh da Karewa ("The New Qissa of the Marriage of an Old Man"), Nawan Qissa Devar Bhabhi da ("The New Qissa of the Love between a Sister-in-law and Brother-inlaw"), and Nawan Qissa Chhare Bilas ("The New Qissa of the Pining of a Bachelor"). Another suggestive title, Ishq Suneha Arthat Jhaggra Randi Launda (1930) by Bhai Nanu Singh is a dialogue between a prostitute and a homosexual and ostensibly a warning against their wiles but provides salacious entertainment as they describe their physical beauty, dressing and ploys of conducting business. Titles such as these "first allow[ed] the pleasure of the transgressive and the forbidden, and then attempt[ed] to contain these elements by invoking dominant moral values" (McCracken, 1993, p. 2).

Horrified at the obscenities that infringe his sense of morality, an officer of the British Government says:

...it would be difficult to concoct books, more immoral in their tendency than the legends, traditions and doctrines, which are instilled into the mind of every Hindoo by his spiritual guides, or the sensual aspirations which Mahomedanism delights in cherishing. It is to be confessed too with sorrow, that Native Indian social life, even after 100 years of British efforts to establish decency, is about as prolific in wantonly degrading every-day circumstances, as the most prurient imagination could put in print. $^{7}$ ( Native Periodicals and Presses, 1858)

On the proposed extension of the provisions of the International Agreement for the suppression of obscene publications to British India, C.R. Cleveland from the Home Department says, "My impression is that the obscene literature imported into India is nothing either in amount or in obscenity to that produced locally and there is little if any exported." 8 The quarterly catalogues of books published in Punjab offer a revelation about the popularity of such ribald titles, mostly in the form of qissas and jhaggras or a dialogue form modelled on these. The Dil Bahlao (entertainment) is one such example that flourished across languages over three to four decades. One particular lithographed version, Majmиa Dil

\footnotetext{
7 "Note on Native Periodicals and Presses," 1858, IOR/V/23/120.

${ }^{8}$ Home Judicial (A), No. 174-75, October 1911.
} 
Bahlao Mein ${ }^{9}$ presents a conversation between seven women who have gone together to fill water from a well. As they complain about their husbands' intoxication and addiction to bhang, charas, opium, and liquor, they talk about their own sexual urges, wasted youth, and unrequited love in terms of the traditional khayal. Thus, the classical genre of short songs that usually describe divine or romantic love is used to call for reform of the evil practice of drinking and at the same time, provide risqué entertainment. Various other versions of the Dil Bahlao abound, some of them being, Qissa-i-Dil Bahlao (Urdu 1890) and Dil Bahlao (Hindi in Persian character, 1890). ${ }^{10}$

The editor of the periodical Bharat Bhagini (Hindi) notes that women are prone to reading 'bad' literature - romances and lurid novels that were increasingly available in Devanagari as well. She expresses frustration at trying to control obscene literature from reaching women and advises parents and husbands not to keep "raseeli pustaken" (amorous books) at home (Bharat Bhagini, June-July 1902). She fears that when women read "shringar" (amatory) novels they become oblivious even to their domestic duties and that such novels are merely written for commercial gains (Bharat Bhagini, November 1903). The editor of the Punjabi periodical Punjabi Bhain complains of obscene baramasas and qissas written by women reaching their office by post for publication (September 1910). The periodicals Bharat Bhaginiand Punjabi Bhain often advertised and recommended new books that would have salutary effects on women readers. At the same time, they also recorded their worry over a 'deviant' readership which did not correspond with their idea of appropriate modernity. Thus, as readers and writers, women did not strictly conform to the genres and languages recommended by reform organisations, thus influencing print spheres in a number of ways.

\section{Results and Discussion}

Most academic work on print cultures in colonial Punjab has paid scant attention to women's presence, participation, and identity-formation in its material and discursive domain. Colonial print culture has generally been seen in terms of state surveillance, censorship, communal propaganda, and nationalism. It is also assumed that women were completely contained within the dominant reform discourse of social morality, religious identity, and nationalism, and hence they could never be resisting presences. This paper sought to bring women into the ambit of investigation of the constitution of public and print discourse in colonial Punjab and examine the political agency of women in these. The archival material used for the study does show that that despite being constituted by state surveillance and elite ideological representations, print discourse also charted independent, specific domains that women inhabited, constituted, and left their mark on. Assumptions about the fixity of religious and linguistic identities and women's containment within the reform discourse in colonial Punjab do not hold. Women's 'resistance' to colonial and reform prescriptions can be located in print and oral cultures, in the languages that they spoke and read, and their choice of genres of reading.

\section{Conclusion}

One of the key points in postcolonial theoretical analysis of structures of colonial oppression is linguistic imperialism and its effects on 'self-identity' in postcolonial cultures. In analyzing the use of language as an oppressive and discursive form of knowledge production by the

\footnotetext{
${ }^{9}$ lithographed, Brihan Press, 1877.

${ }^{10}$ Qissa-i-Dil Bahlao, Tulsi Das, 32 pages, Nawal Kishore, Lahore, Catalogue quarter ending 31 March 1890; Dil Bahlao Guru Gulab Das, Jauhar-i-Hind Press, 32 pages, Catalogue quarter ending 30th June, 1890.
} 
colonial authority, the displacement of local languages, and language as an important part of decolonisation, postcolonial theory solidifies two oppositional categories - vernaculars and metropolitan language, and power hierarchies between the two. In this framework, the processes through which the vernaculars are produced in the context of colonial interventions, and the power hierarchies between competing vernaculars, get erased. This essay re-thinks the postcolonial through an engagement with the formation of print cultures in vernacular languages, and the cultural lives of these languages as inflected by colonial policy. It studies gendered print cultures in late- $19^{\text {th }}$ and early- $20^{\text {th }}$ century Punjab, through the trope of 'resistance' of the colonial subject.

Women's choice of languages and genres for reading and writing is one way in which this 'resistance' and agency can be located. Evidences drawn from publishing records indicate that the robustness of Punjabi language publishing despite not being supported by the government had much to do with women's reading and oral practices. The formulae and prescriptions of religious reform movements that mapped language use to religious identity were defied by entrenched oral and literary habits of women. Assumptions regarding the script-language-religion continuum are complicated by records of translated works, multilingual printing, and the need to reach intended audiences. Historical sources also provide evidence of "deviant" women's readership and consumption patterns that show a different relationship to prescribed taste, moral edification, and popular print.

Women's readership was, thus, influenced by many factors including ideological compulsions, entrenched oral and literary habits, intended audiences, languages of education, desires of modern womanhood, and literary and social prestige. It is through these choices that women, as subalterns, speak in print.

\section{References}

Annual Reports on Publications Registered in Punjab under Act XXV of 1867 and Act X of 1890, 1913 \& 1914.India Office Records [hereafter IOR], IOR/L/PJ/6/1252 \& 1382. Bharat Bhagini. (Hindi periodical, 1902-04). Lahore.

Catalogues of Books Registered in Punjab under Act XXV of 1867 and Act X of 1890. (18671921). IOR, SV 412/44 series.

Dharwadker, Vinay. (1997). Print Culture and Literary Markets in Colonial India. In Jeffrey Masten et al. (Eds.), Language Machines and Technologies of Literary and Cultural Production (pp. 109-36). Routledge.

Fraser, Robert. (2008). Book History Through Postcolonial Eyes: Rewriting the Script. Routledge.

Home Education Proceedings. (1919). National Archives of India, New Delhi [hereafter NAI]. Home Judicial Proceedings. (1911). NAI.

Home Public Proceedings. (1874). NAI. Majmua Dil Bahlao Mein. (lithographed, 1877). Delhi: Brihan Press.

Mir, Farina. (2010). The Social Space of Language: Vernacular Culture in British Colonial Punjab. Permanent Black.

Nijhawan, Shobna. (2012). Women and Girls in the Hindi Public Sphere: Periodical Literature in Colonial North India. Oxford University Press.

Note on Native Periodicals and Presses, 1858, IOR/V/23/119 \&120. Panchal Pandita. (Hindi periodical, 1900-1901). Jalandhar. 
Phillouri, Shraddha Ram. (1887). Bhagyavati: Strishiksha ki Apoorv Pustak (Hindi). Phillour. Punjabi Bhain. (Punjabi periodical, 1910). Ferozepur.

Singh, Mohan. (n.d.) A History of Panjabi Literature (1100-1932). Tutorial Press.

Sivaramakrishnan, Kavita. (2006). Old Potions, New Bottles: Recasting Indigenous Medicine in Colonial Punjab (1850-1945). Orient Longman.

\section{Bio-note}

Dr. Arti Minocha is an Associate Professor at the Department of English at Lady Shri Ram College, Delhi University. She has taught various courses in Indian Literature, Modern British Literature, World Literatures and Afro-American Literature. She has published in the areas of Indian Theatre, Print Culture Studies and South Asian Women's Histories. Her current research project seeks to re-inscribe women into histories of print and literary cultures and language debates in colonial Punjab.

Email Id: artiminocha@1sr.edu.in 